\title{
Polychaete invader enhances resource utilization in a species-poor system
}

\author{
Agnes M. L. Karlson • Johan Näslund • \\ Sara Blomgren Rydén · Ragnar Elmgren
}

Received: 6 July 2010/ Accepted: 2 February 2011 / Published online: 23 February 2011

(c) The Author(s) 2011. This article is published with open access at Springerlink.com

\begin{abstract}
Ecosystem consequences of biodiversity change are often studied from a species loss perspective, while the effects of invasive species on ecosystem functions are rarely quantified. In this experimental study, we used isotope tracers to measure the incorporation and burial of carbon and nitrogen from a simulated spring phytoplankton bloom by communities of one to four species of deposit-feeding macrofauna found in the species-poor Baltic Sea. The recently invading polychaete Marenzelleria arctia, which has spread throughout the Baltic Sea, grows more rapidly than the native species Monoporeia affinis, Pontoporeia femorata (both amphipods) and Macoma balthica (a bivalve), resulting in higher biomass increase (biomass production) in treatments including the polychaete. Marenzelleria incorporated and buried bloom material at rates similar to the native species. Multi-species treatments generally had higher isotope incorporation, indicative of utilization of bloom material, than expected from monoculture yields of the respective species. The mechanism behind this observed over-yielding was mainly niche complementarity in utilization of the bloom input, and was more evident in communities including the invader. In contrast, multi-species treatments had generally lower biomass increase than expected. This contrasting
\end{abstract}

Communicated by Ulrich Sommer.

A. M. L. Karlson $(\varangle)$ · J. Näslund · S. B. Rydén · R. Elmgren Department of Systems Ecology, Stockholm University, 10691 Stockholm, Sweden

e-mail: agnes@ecology.su.se

Present Address:

J. Näslund

AquaBiota Water Research, Svante Arrhenius väg 21A,

11418 Stockholm, Sweden pattern suggests that there is little overlap in resource use of freshly deposited bloom material between Marenzelleria and the native species but it is likely that interference competition acts to dampen resulting community biomass. In conclusion, an invasive species can enhance incorporation and burial of organic matter from settled phytoplankton blooms, two processes fundamental for marine productivity.

Keywords Bioturbation - Empty niche - Exotic species · Resource partitioning $\cdot$ Selection effect

\section{Introduction}

The link between biodiversity and ecosystem functioning (e.g., productivity, elemental cycling and trophic transfer of energy) is still far from fully understood (Loreau et al. 2001; Hooper et al. 2005). Motivated by global declines in biodiversity due to human activities, most studies on this topic have focused on the consequences of species loss (Stachowicz et al. 2007). But ecosystems also face significant pressure from the addition of invasive species due to human activities (e.g., Vitousek et al. 1997; Chapin et al. 2000). Direct and dramatic consequences of invaders, such as extinction of native species, are well known (e.g., Witte et al. 1992), but less is known about their effects on ecosystem functioning (but see, e.g., Heath et al. 1995; Vander Zanden et al. 1999; Townsend 2003; Byrnes and Stachowicz 2009) and on the mechanisms causing the observed effects.

Successful invaders are believed to often possess one or several unique traits, which either make them functionally dissimilar from the resident species, allowing them to occupy a different niche (Elton 1958; Shea and 
Chesson 2002), or make them competitively superior to the native species. Superior competitive ability may manifest itself through interference or exploitative competition, with consumption rate and food conversion efficiency being especially important determinants of the latter (Byers 2000).

Recently, evidence has accumulated indicating a positive relationship between species richness and ecosystem function (e.g., Cardinale et al. 2006; Duffy 2009). However, the ecological mechanisms driving observed community relationships remain an understudied topic. Commonly, species performances are compared between monocultures and polycultures (multi-species treatments). The difference between the measured yield (for any given ecosystem function) and the expected yield (derived from the species' yields in monoculture) can be either positive due to niche partitioning or facilitative interactions between species (positive complementarity), or negative due to competition and inhibition (negative complementarity). It can also be attributed to the selection or dominance "effect", where a species can become dominant in polycultures through competition or because their traits are favored under particular environmental conditions (Loreau and Hector 2001; Hector et al. 2002; Fox 2005). Hence, the dominance effect can be positive or negative depending on how well the dominant species performs in monoculture.

Complementarity and the dominance effect can be mathematically separated from each other when speciesspecific contributions to the measured characteristic in a polyculture can be estimated (Loreau and Hector 2001; Fox 2005). This approach, in well-designed experiments, can be used to obtain a mechanistic understanding of observed relationships between biodiversity and ecosystem functioning (e.g., Karlson et al. 2010) and for understanding the factors determining invasion success (Wilsey et al. 2009).

The naturally low species richness in Baltic Sea sediments is ideal for studies on the effect of an invasive species on the link between biodiversity and ecosystem function, since the regulating mechanisms are easier to understand than in more species-rich systems (Elmgren and Hill 1997; Karlson et al. 2010). Only three species (the amphipods Monoporeia affinis and Pontoporeia femorata and the bivalve Macoma balthica) represent the native deposit-feeding macrofaunal guild of sub-thermocline softbottoms of the northern Baltic Sea proper (Ankar and Elmgren 1976). Species richness is even further reduced as salinity decreases further north in the Baltic Sea, and in oxygen-deficient deeper areas. In recent years, three species of the deposit-feeding polychaete genus Marenzelleria (M. viridis, M. neglecta and $M$. arctia) have invaded the Baltic Sea (Leppäkoski et al. 2002; Blank et al. 2008), providing an opportunity for experiments relevant to field situations on species addition and how it may affect ecosystem function (Loreau et al. 2001; Bracken et al. 2008).

Ecosystem processes performed by deposit-feeders that process energy and elements that connect the two largest habitats on earth, the benthic and pelagic systems, (Snelgrove et al. 1997) are referred to as ecosystem functions in this paper. Deposit-feeders inhabiting sediment below the photic zone are critically dependent on settled organic matter from phytoplankton blooms, with the spring bloom of diatoms constituting the largest annual input to the benthos in temperate waters (Graf 1992), including the Baltic Sea (Elmgren 1978). When eaten by fish, phytodetritus-feeding macrofauna are an important trophic link back to the pelagic system. In addition, macrofaunal burrowing and feeding activities in the sediment (bioturbation) can either enhance mineralisation of organic matter (Kristensen 2000; Bianchi et al. 2000) or slow it down, by burying it deeper in the sediment (van de Bund et al. 2001).

We studied communities of one to four species of deposit-feeding macrofauna that can be found together in the field. The four studied species differ in their feeding and sediment reworking activities; they include surface and sub-surface feeders with varying degrees of motility (Lopez and Elmgren 1989; Viitasalo-Frösen et al. 2009; Karlson et al. 2010). We measured their biomass increase (biomass production), incorporation and burial of organic matter from a simulated spring phytoplankton bloom using isotope tracers. By doing so, we could quantify the incorporation of bloom material across individual species, enabling a mathematical partitioning of observed community level effects into diversity components according to Fox (2005). This approach made it possible to make detailed ecological interpretations of the consequences that an invasive species may have on community interactions and to relate observed differences among treatments to species-specific traits. We hypothesised that species richness would affect biomass increase, as well as incorporation and burial of organic matter by deposit-feeders, and that non-additive effects would be explained by complementarity among species and the dominance effect.

\section{Materials and methods}

\section{Experimental design}

A substitutive design was used (Stachowicz et al. 2007), keeping the total density of animals constant while varying species richness $(1,2,3$ or 4$)$. Only species combinations common in Baltic Sea benthos were included in the experimental set-up. The four species, Monoporeia affinis, Pontoporeia femorata, Macoma balthica and Marenzelleria spp. are hereafter referred to as Monoporeia, 
Pontoporeia, Macoma and Marenzelleria in the text and abbreviated $\mathrm{Ma}, \mathrm{Pf}, \mathrm{Mb}$ and $\mathrm{Mz}$, respectively, when referring to the different treatments included in the experiment. In short, a settling bloom was simulated by supplying labeled phytoplankton to microcosms containing sediment and different animal communities and the uptake and burial of the bloom material were measured (details below). The following treatments were tested: four singlespecies treatments, or monocultures ( $\mathrm{Ma}, \mathrm{Pf}, \mathrm{Mb}$, and $\mathrm{Mz}$ ), four 2-species combinations ( $\mathrm{Ma}+\mathrm{Pf}, \mathrm{Ma}+\mathrm{Mb}$, $\mathrm{Ma}+\mathrm{Mz}$, and $\mathrm{Mb}+\mathrm{Mz}$ ), three 3-species combinations $(\mathrm{Ma}+\mathrm{Pf}+\mathrm{Mb}, \mathrm{Ma}+\mathrm{Pf}+\mathrm{Mz}$, and $\mathrm{Ma}+\mathrm{Mb}+\mathrm{Mz})$ and one 4-species combination ( $\mathrm{Ma}+\mathrm{Pf}+\mathrm{Mb}+\mathrm{Mz})$. We also included treatments without addition of phytoplankton to each species in monoculture to quantify growth of fauna feeding on sediment without the bloom input (Controls). All treatments had five replicates.

\section{Study organisms}

Monoporeia is a surface-feeding amphipod, Pontoporeia a subsurface-feeding amphipod (Byrén et al. 2006) while the polychaete Marenzelleria and the bivalve Macoma are facultative suspension and deposit feeders (Dauer et al. 1981; Ólafsson et al. 2005). Marenzelleria spp. differ functionally from the native species primarily by burrowing deeper (up to $35 \mathrm{~cm}$ compared to about $5 \mathrm{~cm}$ ), which influences the cycling of both nutrients (Hietanen et al. 2007; Norling et al. 2007; Viitasalo-Frösen et al. 2009) and contaminants (Hedman et al. 2008). The Marenzelleria individuals used in this experiment are most likely $M$. arctia, which inhabits deep muddy bottoms $(<20 \mathrm{~m})$ in the study area (Blank et al. 2008), as they agree morphologically with this species in the identification key of Bick (2005).

\section{Collection of sediment and animals}

Animals and surface sediment (approx. 0-5 cm) were collected with an epibenthic sledge in March 2008, before the onset of the spring bloom, from about $30 \mathrm{~m}$ depth in the Askö area, NW Baltic Sea $\left(58^{\circ} 49^{\prime} \mathrm{N}, 17^{\circ} 31^{\prime} \mathrm{E}\right)$. The sediment was sieved through a $500-\mu \mathrm{m}$ mesh, with minimum of water, to remove all macrofauna, and was then left to settle in aerated containers in a constant temperature room at $4{ }^{\circ} \mathrm{C}$ with faint green light $(<5 \mu \mathrm{E})$ (in situ conditions). After sampling for stable isotopes and content of nitrogen (N) and carbon (C), the sieved and settled sediment was divided among 1-L plastic jars (microcosms) to a depth of $5 \mathrm{~cm}$ (surface area $80 \mathrm{~cm}^{2}$ ). The microcosms were filled to the rim with filtered Baltic Sea water (salinity 6) and were then aerated without disturbing the surface of the sediment. The collected animals were separated according to species and then left in weak green light $(<5 \mu \mathrm{E})$ in aerated containers with brackish seawater and $3-5 \mathrm{~cm}$ of unsieved sediment at $4^{\circ} \mathrm{C}$ until the start of the experiment.

Sampling and incubation of spring bloom material

Spring bloom material was collected with a $15-\mu \mathrm{m}$ plankton net in Himmerfjärden $\left(59^{\circ} 03^{\prime} \mathrm{N}, 17^{\circ} 41^{\prime} \mathrm{E}\right)$ on 14 April 2008. The algae were divided on several Erlenmeyer-flasks and brackish water (salinity 6) was added $(500 \mathrm{~mL}$ in each). The algae were then incubated on a shaking table in constant light at $5^{\circ} \mathrm{C}$ with nutrients (f/2 medium with silica) (Guillard 1975) in which all carbon (C) and nitrogen (N) had been replaced with the enriched equivalents, $\mathrm{NaH}^{13} \mathrm{CO}_{3}$ and ${ }^{15} \mathrm{NH}_{4} \mathrm{Cl}$ (Cambridge isotopes, 99\% heavy isotope). After 5 days of incubation the algal cultures were pooled, homogenized, sieved through $40 \mu \mathrm{m}$ and rinsed with brackish water to remove non-incorporated isotopes. Samples were taken for stable isotope analyses (2 mg dry biomass, rinsed with distilled water) and taxonomic analysis. The harvested algal suspension was then frozen at $-20^{\circ} \mathrm{C}$ until the experiment was started. The isotopelabelled spring bloom material was dominated by the diatom Thalassiosira balthica. See Table 1 for isotope values of initial sediment and animals and of the enriched algae.

Start and termination of the experiment

On 21 April 2008, 24 adult macrofaunal individuals were added to each microcosm, corresponding to a field-relevant density of 3,300 ind $\mathrm{m}^{-2}$ (Ankar and Elmgren 1976). We attempted to select individuals of similar size and biomass for all species to reduce interpretation problems due to size-dependent physiological differences. The adult $(1+)$ Monoporeia individuals were, however, inevitably smaller than the other species (Table 1), since their main growth period is after the spring bloom (Cederwall 1979). All individuals used were well below the maximum known size for their species in the Baltic Sea. After the animals had burrowed in the sediment, the labeled algae (26.4 $\mathrm{mg} \mathrm{dw}$ corresponding to $0.7 \mathrm{~g} \mathrm{C} \mathrm{m}^{-2}$ ) were added to the sediment surface with a Pasteur pipette. The amount added corresponds to a minor sedimentation event in the Askö area (Höglander et al. 2004). The microcosms were then sealed with parafilm and reconnected to the air system. After 10 days, distilled water was added to compensate for loss through evaporation.

The experiment was terminated after 3 weeks. As a rough indicator of oxygen conditions in the sediment, we measured the depth of the oxidized layer, from the sediment surface to the sharp color change characterizing the apparent redox potential discontinuity layer, at three random points of each microcosm. A small sediment core 
Table 1 Isotope values, biomass $(\mathrm{mg}), \mathrm{C}$ and $\mathrm{N}$ content and $\mathrm{C} / \mathrm{N}$ ratio $(\mathrm{wt} / \mathrm{wt})$ of sediment $(n=3)$, algae $(n=3)$ and animals $(n=10)$ at the start of the experiment

\begin{tabular}{lcccrrr}
\hline & \multicolumn{1}{c}{$\delta^{15} \mathrm{~N}$} & \multicolumn{1}{c}{$\delta^{13} \mathrm{C}$} & Biomass & \multicolumn{1}{c}{$\mathrm{C} \%$} & $\mathrm{~N} \%$ & $\mathrm{C} / \mathrm{N}$ \\
\hline Sediment & $6.8 \pm 0.2$ & $-23 \pm 0.1$ & - & $3.9 \pm 0.1$ & $0.6 \pm 0.0$ & $7.1 \pm 0.1$ \\
Algae & $139,800 \pm 1,300$ & $2,460 \pm 10$ & - & $21.3 \pm 0.1$ & $3.8 \pm 0.1$ & $5.6 \pm 0.1$ \\
Monoporeia & $10.8 \pm 2.0$ & $-19.8 \pm 0.4$ & $0.7 \pm 0.3$ & $32.5 \pm 1.6$ & $8.0 \pm 0.5$ & $4.1 \pm 0.2$ \\
Pontoporeia & $9.5 \pm 2.0$ & $-21.9 \pm 0.5$ & $1.2 \pm 0.2$ & $43.7 \pm 2.8$ & $8.3 \pm 0.5$ & $5.3 \pm 0.4$ \\
Macoma & $12.2 \pm 1.8$ & $-20.8 \pm 0.4$ & $1.0 \pm 0.4$ & $41.4 \pm 1.9$ & $10.0 \pm 0.5$ & $4.1 \pm 0.1$ \\
Marenzelleria & $11.5 \pm 1.0$ & $-21.7 \pm 0.3$ & $1.6 \pm 0.5$ & $43.5 \pm 2.0$ & $10.7 \pm 0.9$ & $4.1 \pm 0.3$ \\
\hline
\end{tabular}

Values are mean $\pm \mathrm{SD}$

(diameter $1.5 \mathrm{~cm}$ ) was then taken from all replicates using a cut-off syringe, and directly frozen in an upright position. The frozen cores were sliced into two layers, $0-1 \mathrm{~cm}$ depth and $1-4 \mathrm{~cm}$ depth. Each layer was homogenized and weighed before and after drying at $60^{\circ} \mathrm{C}$. Approximately $15 \mathrm{mg}$ of the dry sediment from each slice was put in $5 \times 8 \mathrm{~mm}$ tin capsules for stable isotope analyses. The remaining sediment was sieved through $500 \mu \mathrm{m}$ and all animals were counted and placed in seawater for a few hours to empty their gut. Next, the animals were rinsed with distilled water, dried at $60^{\circ} \mathrm{C}$, weighed (bivalves after shell removal) and put in tin capsules for stable isotope analyses.

Stable isotope analyses

Samples of the spring bloom material, animals and sediment were analysed for elemental and stable isotope content ( $\mathrm{C}$ and $\mathrm{N})$ at the UC Davis Stable Isotope Facility, USA. Three whole animals per species and replicate were analysed individually, as uptake is known to be highly variable. Before statistical evaluation, the analytical replicates were averaged within species for each microcosm. The $\mathrm{C}$ and $\mathrm{N}$ isotope ratios are expressed in the \%o notation, using the equation:

$\delta R(\%)=\left(\left[R_{\text {sample }} / R_{\text {standard }}\right]-1\right) \times 10^{3}$

where $R$ is the ratio between the heavy and light isotopes $\left({ }^{13} \mathrm{C}:{ }^{12} \mathrm{C}\right.$ or $\left.{ }^{15} \mathrm{~N}:{ }^{14} \mathrm{~N}\right)$. The stable isotope ratio, denoted by $\delta$, is defined as the deviation in \%o from an international reference standard (Vienna PeeDee Belemnite for C, and atmospheric nitrogen gas for $\mathrm{N}$ ). Higher $\delta$ values indicate a higher proportion of the heavy isotope. Samples were run in continuous flow with a standard deviation of $<0.2 \%$ among replicate standard samples for both $\mathrm{C}$ and $\mathrm{N}$.

\section{Calculations}

To quantify diatom $\mathrm{C}$ and $\mathrm{N}$ incorporated by the macrofauna or remaining in the sediment, a linear two-source mixing model was used for each element separately (Karlson et al. 2010):

$f_{1}+f_{2}=1 ; f_{1}=\left(\delta_{\text {sample }}-\delta_{\text {source } 2}\right) /\left(\delta_{\text {source } 1}-\delta_{\text {source } 2}\right)$

where $f_{1}$ is the proportion of diatom $\mathrm{C}$ or $\mathrm{N}$ in the sample (animal or sediment) and $f_{2}$ is the proportion of $\mathrm{C}$ or $\mathrm{N}$ derived from the initial sediment. The amount $(\mathrm{mg})$ of diatom $\mathrm{C}$ and $\mathrm{N}$ incorporated in each animal was calculated from the mixing model and the total $\mathrm{C}$ and $\mathrm{N}$ content $(\mathrm{mg})$ in the animal and was then multiplied by the number of surviving individuals in the replicate to obtain community incorporation of diatom $\mathrm{C}$ and $\mathrm{N}$ from the fresh bloom material. In communities containing more than one species, the species-specific total incorporation values (based on replicate-specific survival) were summed. The amount of $\mathrm{C}$ and $\mathrm{N}$ of diatom origin in the sediment was calculated from the mixing model by taking the water and $\mathrm{C}$ and $\mathrm{N}$ content of each sediment layer into account and summing all layers. Recovery of diatom $\mathrm{C}$ and $\mathrm{N}$ in fauna and sediment was calculated as the fraction of the initial addition $(100 \%)$ of labeled $\mathrm{C}$ and $\mathrm{N}$ that was either incorporated by the community or remained in the sediment.

Expected values of biomass increase and incorporation of $\mathrm{C}$ and $\mathrm{N}$ in multi-species treatments were calculated as the weighted average of the corresponding single-species treatments, taking mortality into account. The difference between observed and expected values, the net effect, could be separated into three components according to Fox (2005): Trait-independent complementarity (TIC) (equal to complementarity in Loreau and Hector 2001), traitdependent complementarity (TDC) and dominance (D). The components are calculated using an equation where changes in relative performance (yield) among components species are examined within and between treatments. Positive TIC suggests low niche overlap and occurs if species yields in a mixture are on average higher than expected from the weighted average monoculture yield of the component species. Negative TIC suggests competition or inhibition. Positive trait-dependent complementarity suggests that species with wide niches attain high 
monoculture yield and high relative yield in mixtures but not at the expense of other species with narrow niches. Dominance quantifies the extent to which a species performing well in monoculture achieves high relative yield in mixtures at the expense of species performing less well in monoculture.

\section{Statistical analyses}

The performance of species in their respective monocultures were compared using an ANOVA with individual incorporation of ${ }^{13} \mathrm{C}$ or ${ }^{15} \mathrm{~N}$ (measured as isotope value $e_{\text {end }}-$ value $_{\text {initial}}$ ), individual biomass increase, burial of bloom material or depth of the oxidised layer as the response variable. The effects of species richness and species composition were tested in a nested ANOVA (Jonsson and Malmqvist 2000), where species composition (treatments) was nested under species richness (1, 2, 3 and 4), with community incorporation of $\mathrm{C}$ and $\mathrm{N}$ (both using raw data and data where incorporation was normalized for community biomass), community biomass increase and burial of $\mathrm{C}$ and $\mathrm{N}$ into the sediment as response variable. Species composition was viewed as a fixed factor nested under species richness, since the species compositions used represented actual species compositions found in the field, not random selections from a larger species pool. Data that did not meet the requirements of an ANOVA were tested for differences among treatments with non-parametric KruskalWallis. Data on burial of C and N were lost from one replicate in the Ma treatment. Residual plots were visually inspected and when needed to obtain variance homogeneity, the data were log- or square-root-transformed before testing, except that survival (\%) was arcsine-transformed. All analyses were performed in STATISTICA 8.0 (Statsoft).

\section{Results}

Survival and growth of fauna

Survival in the different treatments ranged between 93 and $100 \%$ for all species except Monoporeia, which had a survival of $71 \pm 6 \%$, with no differences among treatments (Kruskal-Wallis $H_{8,45}=6.21, \quad P=0.62$ ). All species increased in individual biomass when given settling bloom material (shown as community biomass increase in Fig. 1), with significant differences in growth among species in their respective monocultures (Kruskal-Wallis, $H_{3,19}=13.71$, $P=0.003)$. In monocultures, Monoporeia and Pontoporeia increased by about $20 \%$ compared to initial values, Macoma by $60 \%$ and Marenzelleria by $70 \%$. Among treatments that received settling bloom material (excluding "Controls"), there was no difference in individual growth for Monoporeia

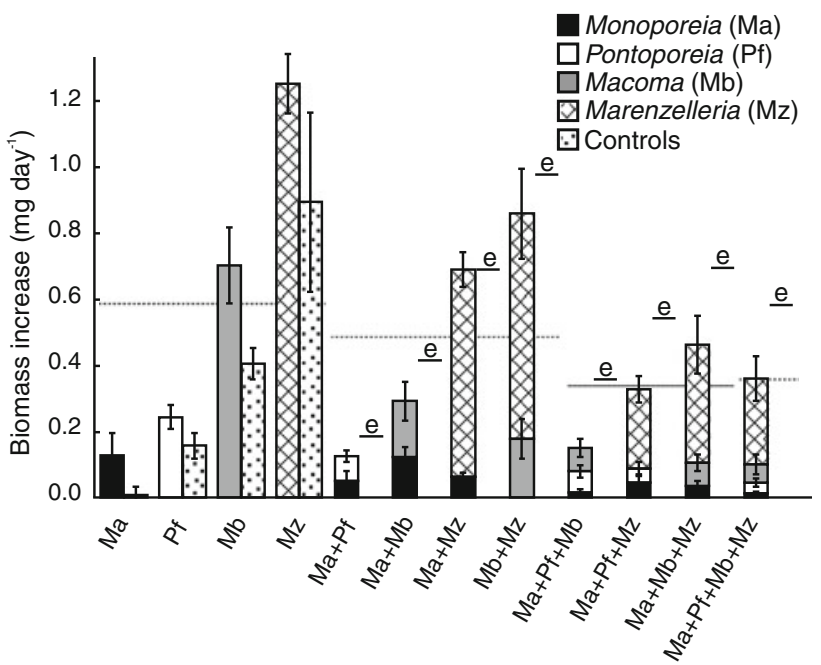

Fig. 1 Observed biomass increase of three native $(M a, P f, M b)$ and one invader $(M z)$ marine invertebrate species in monoculture versus control and in 2, 3, and 4-species treatments, mean \pm SE. For monocultures, biomass increases in control microcosms with sediment as the sole food source is also shown. Expected values $(e)$ based on biomass increase in monoculture are shown for multi-species treatments. Dashed lines represent the averages of monocultures, 2, 3, and 4-species treatments, respectively. See text for statistically significant differences

and Marenzelleria (ANOVA $F_{7,32}=1.68, P=0.14$ and $F_{5,24}=0.97, P=0.45$, respectively). Pontoporeia and Macoma showed differences in growth among treatments $\left(F_{4,20}=3.54, P=0.024\right.$ and $F_{5,24}=2.74, P=0.043$, respectively), most notably for Macoma, which had higher growth in monoculture than in its other treatments. The lower initial biomass (Table 1), lower survival and lower growth (Fig. 1) of Monoporeia resulted in lower final community biomass (data not shown) for treatments with high Monoporeia density (Kruskal-Wallis $H_{11,60}=47.20$, $P<0.001)$.

In the control treatments without bloom input, differences in growth among species were also recorded (Fig. 1; Kruskal-Wallis, $\left.H_{3,19}=15.41, P=0.001\right)$. All species except Monoporeia grew in individual biomass, Pontoporeia by $12 \%$, Macoma by $35 \%$ and Marenzelleria by $50 \%$. When fed diatoms (in monoculture) Macoma grew significantly, and Monoporeia nearly significantly, more than in their respective control treatments (Fig. 1; ANOVA, $\quad F_{1,8}=5.63, \quad P=0.045$ and $F_{1,8}=5.27$, $P=0.055)$, but this trend was not significant for Pontoporeia and Marenzelleria $\left(F_{1,8}=2.98, P=0.12\right.$ and $F_{1,8}=1.54, P=0.25$, respectively).

Incorporation of $\mathrm{C}$ and $\mathrm{N}$ by individual species

All species incorporated significant amounts of the bloom material during the experiment, as seen in their highly 
enriched isotope values (Fig. 2). Their respective individual incorporation in monoculture differed significantly, with Monoporeia and Macoma showing the highest and Pontoporeia the lowest incorporation of both $\delta^{13} \mathrm{C}$ and $\delta^{15} \mathrm{~N}$ (ANOVA, $F_{3,16}=15.13, P<0.001$ and $F_{3,16}=$ $15.21, P<0.001)$. All species except Macoma had higher incorporation of both $\delta^{13} \mathrm{C}$ and $\delta^{15} \mathrm{~N}$ in multi-species treatment than in their respective monocultures, with significant difference among treatments for Monoporeia (ANOVA, $\delta^{13} \mathrm{C}: F_{7,32}=2.37, P=0.04$ and $\delta^{15} \mathrm{~N}$ : $\left.F_{7,32}=3.62, P<0.01\right)$.

\section{Community level endpoints}

Species composition (treatments) but not species richness had a significant effect on community biomass increase (nested ANOVA $F_{8,48}=15.41, P<0.000$ and $F_{3,48}=$ $1.27, P=0.30$ for species composition and species richness, respectively). This was mostly due to under-yielding by Macoma in multi-species treatments (Fig. 1). Both species composition and species richness significantly affected community incorporation of diatom N (Fig. 3a; nested ANOVA, $F_{8,48}=23.00, P<0.001$ and $F_{3,48}=$ $3.89, P=0.014$, for species composition and species richness, respectively). The effect of species richness was slightly positive, since all species except Macoma had higher $\mathrm{N}$ incorporation in multi-species treatments than in monoculture (compare Fig. 2). Only composition significantly affected community incorporation of diatom $\mathrm{C}$ (Fig. 3b; $\quad F_{8,48}=9.14, \quad P<0.001$ and $F_{3,48}=0.817$, $P=0.49$ for species composition and species richness, respectively). When incorporation data were tested after normalization to remove the influence of differences in initial biomass, the same results were found (data not shown). Similarly, both species composition and richness

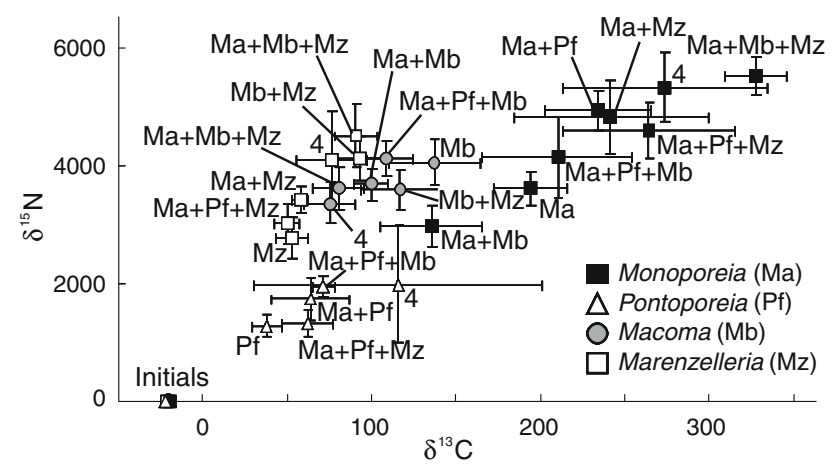

Fig. 2 Isotope values of animals before (initials, lower left) and after feeding on labeled algae for each species (see the specific symbols in the figure) in all tested species combinations, mean $\pm \mathrm{SE}$. The four species treatment $\mathrm{Ma}+\mathrm{Pf}+\mathrm{Mb}+\mathrm{Mz}$ is abbreviated in the figure with 4. Higher isotope values indicate greater incorporation of diatoms was significant for burial of diatom $\mathrm{N}$ (Fig. 4a; nested ANOVA $F_{8.47}=3.75, \quad P=0.002$ and $F_{3,47}=3.00$, $P=0.040$ ) but only composition for burial of diatom $\mathrm{C}$ (Fig. $4 \mathrm{~b}$; nested ANOVA $F_{8,47}=3.50, P=0.010$ and $F_{3,47}=1.16, P=0.33$ ).

The depth of the oxidized layer differed significantly among treatments (Fig. 4c; Kruskal-Wallis, $H_{11,60}=$ 43.80, $P<0.001)$. When tested for differences among monocultures, Marenzelleria and Pontoporeia buried most $\mathrm{N}$ and $\mathrm{C}$ (Fig. $4 \mathrm{a}$, b; N: ANOVA, $F_{3,15}=5.77, P=0.008$ and C: Kruskal-Wallis $H_{3,17}=7.94, P=0.047$ ) while Pontoporeia created the deepest oxygenated layer (Fig. 4c; $\left.H_{3,20}=11.25, P=0.011\right)$.

Partitioning of the diversity effect

The net effect of biodiversity (difference between observed and expected community yield) on biomass increase was negative in all treatments, and the reason for this was generally negative complementarity and negative dominance (Fig. 5a), with Macoma being especially negatively affected in multi-species treatments (compare Fig. 1).

In contrast, the net diversity effect on community incorporation of both $\mathrm{N}$ and $\mathrm{C}$ was positive in all multispecies treatments except for $\mathrm{Ma}+\mathrm{Mb}$ and $\mathrm{Ma}+\mathrm{Pf}+$ $\mathrm{Mb}$ (also for biomass-normalised data) (Fig. 3a, b).

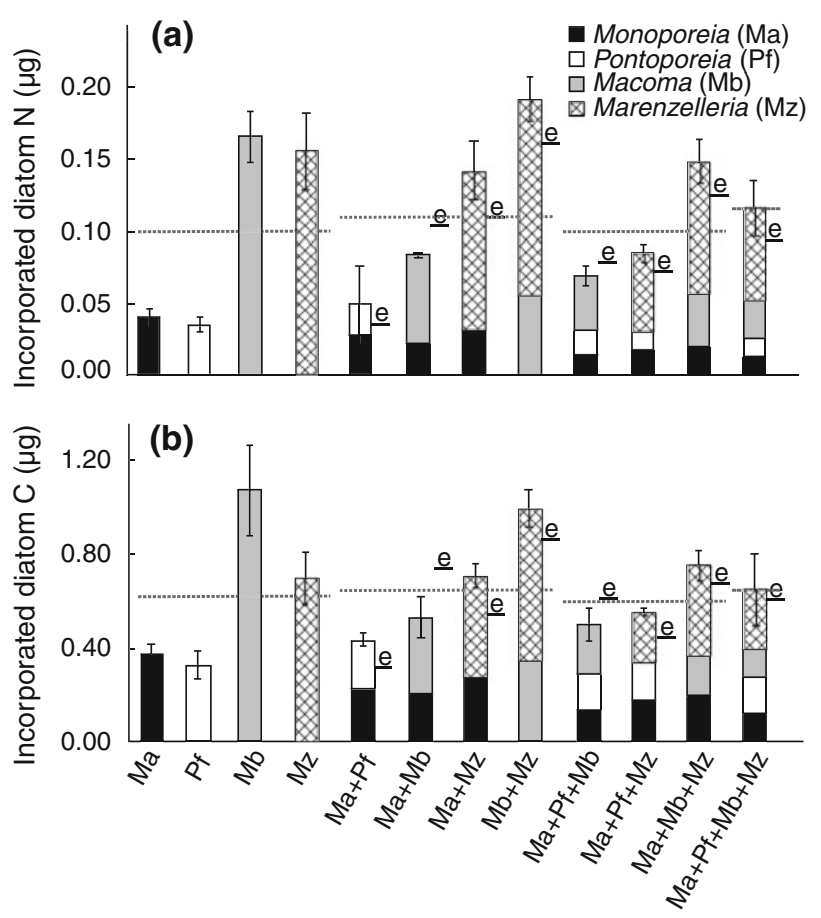

Fig. 3 Observed incorporation of $\mathbf{a}$ nitrogen and $\mathbf{b}$ carbon from bloom material, mean \pm SE. Dashed lines represent the averages of monocultures, 2, 3, and 4-species treatments, respectively. Expected values $(e)$ based on incorporation in monoculture are shown for multispecies treatments. See text for statistically significant differences 

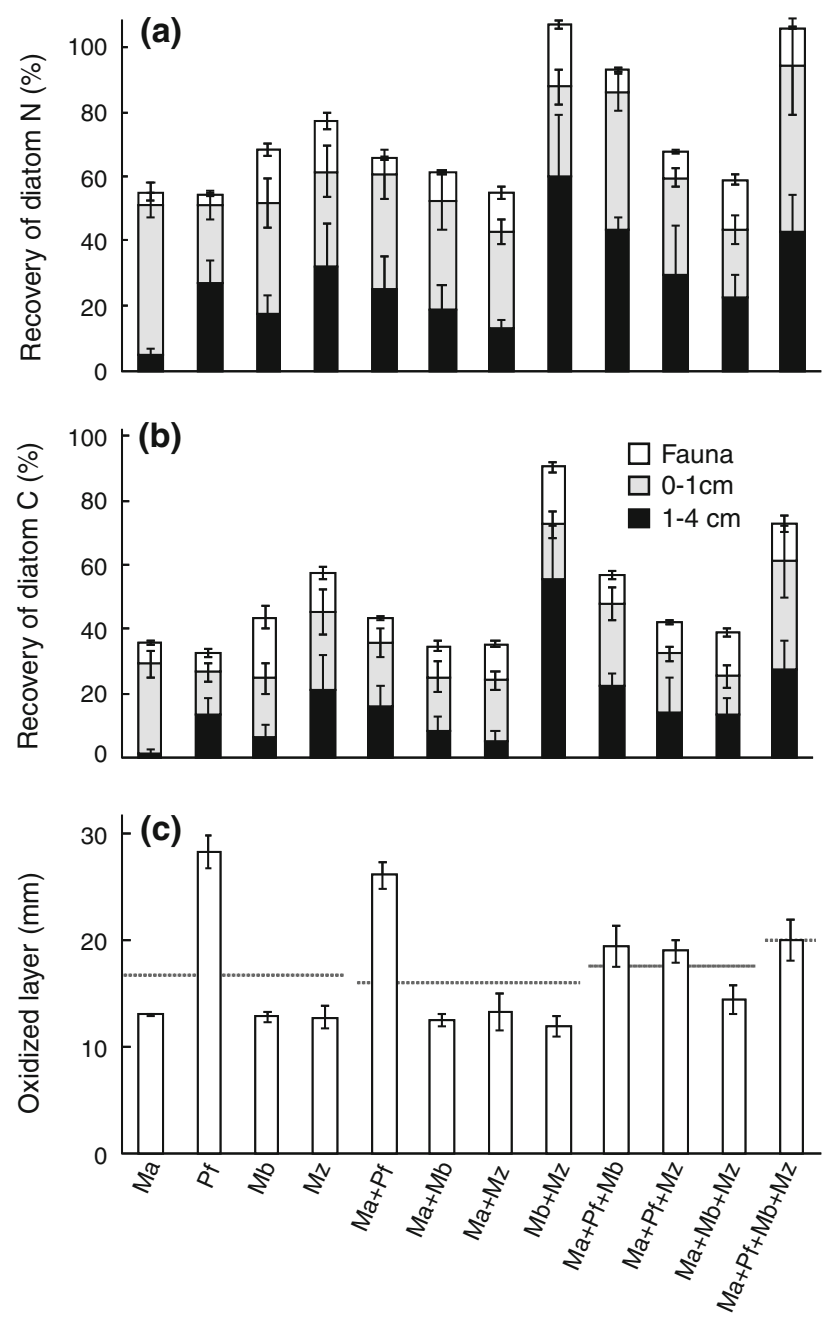

Fig. 4 Recovery of diatom a nitrogen and $\mathbf{b}$ carbon, in sediment (0-1 and $1-4 \mathrm{~cm}$ ) and in fauna. c The depth of the oxidized layer in the different treatments. Values are mean \pm SE. Dashed lines are the averages of monocultures, 2, 3, and 4-species treatments, respectively. Recovery values exceeding $100 \%$ are not statistically significant and presumably due to sub-sampling effects. See Figs. 1 or 3 for explanation of the treatment abbreviations and text for statistically significant differences

Partitioning of the net effect into tripartite components (Fig. 5b, c) revealed that trait-independent complementarity (TIC) was the main cause of this positive net diversity effect but was counteracted by negative dominance, resulting in a small net effect. Interestingly, TIC was always positive in treatments including Marenzelleria, which had higher than expected incorporation values and biomass increase when mixed with other species (compare Figs. 1 and 2). To investigate the potential influence due to differences in biomass among the species on the partitioning results, we also performed calculations assuming equal individual biomass $(1 \mathrm{mg})$ for species and treatments. As the same main pattern was found (TIC the largest diversity component and positive in all treatments
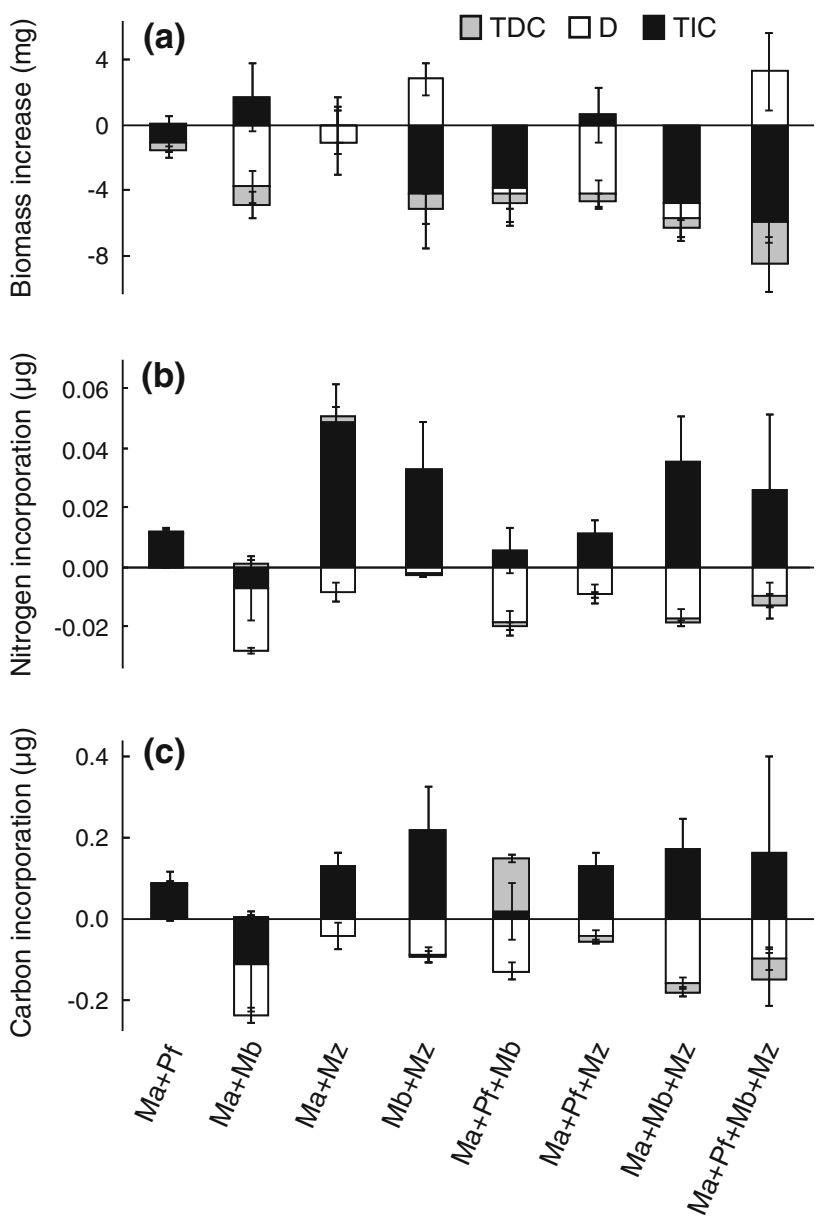

Fig. 5 The net effect for a biomass increase and incorporation of diatom b nitrogen and c carbon, partitioned into the diversity components in the different treatments, mean $\pm \mathrm{SE}$. TDC traitdependent complementarity, $D$ dominance, TIC trait-independent complementarity. See Figs. 1 or 3 for explanation of the treatment abbreviations and text for interpretation of the diversity components

except for $\mathrm{Ma}+\mathrm{Mb}$ ), we have chosen to show the data without biomass adjustments in Fig. 5b, c.

\section{Discussion}

We measured incorporation and burial of labeled phytoplankton bloom material, macrofaunal biomass increase and depth of the oxidized layer in sediment microcosms with natural communities composed of one to four species of native and non-indigenous deposit-feeding macrofauna. There were differences among the four species in how they bioturbated and used resources, supporting a multi-functionality approach (Duffy et al. 2003; Gamfeldt et al. 2008). For example, while the surface-feeders Monoporeia and Macoma showed the highest individual incorporation of bloom material, the sub-surface feeder Pontoporeia and the deep-burrowing Marenzelleria buried the greatest 
amount of bloom material. Interestingly, there was no richness effect on biomass increase alone (often the only studied function in biodiversity-ecosystem functioning studies), but significant richness effects were detected for incorporation and burial. Biomass increase is influenced by many factors (e.g., individual variation in initial lipid and glycogen reserves or need for active defense), hence incorporated organic matter can be allocated for reproduction or maintenance rather than somatic growth. The higher incorporation in multi-species treatments may not have resulted in higher faunal biomass if individuals were simultaneously required to spend more energy on active defence or resource acquisition. That multi-species treatments over-yielded with regard to incorporation of fresh material, yet displayed under-yielding in biomass increase, shows that biodiversity-ecosystem functioning relationships can be difficult to predict and interpret even in an ecosystem of low macrofaunal diversity.

Species richness increased not only the incorporation of $\mathrm{N}$ from the diatom bloom material, but also its burial, indicating that sediments inhabited by a species-rich community are likely to maintain a higher long-term resource utilization, in accordance with Karlson et al. (2010). Higher than expected incorporation in multi-species treatments was due to all species, except the bivalve Macoma, generally increasing their relative yield when combined with other species. According to the partitioning model, this higher relative yield in multi-species treatments was due to mainly positive trait-independent complementarity. Complementarity is a broad class of mechanisms, including facilitation, niche partitioning, density-dependence and if negative, competition and inhibition. The well-known ecology of the species in this study provides some insight into these mechanisms, which we discuss in detail in the following paragraphs.

The generally increased relative yield with species richness for the amphipod Monoporeia can partly be explained by release from intra-specific competition (Elmgren et al. 2001; McKie et al. 2008) as the experiment had a substitutive design. However, its incorporation was lowest when combined with Macoma $(\mathrm{Ma}+\mathrm{Mb})$, and the result from the partitioning model in this treatment gives the only indication of competition over bloom input. Also on a local scale in the field, these species seldom co-occur in high abundances (Segerstråle 1973). Though both are surface feeders, the strategy employed differs at a finer resolution. Macoma is highly efficient in feeding on the sediment surface, by extending its siphon (Ólafsson et al. 2005), whereas the feeding activity of the more motile Monoporeia probably results in dilution of the bloom material in the upper centimeter of the sediment, decreasing the incorporation efficiency of bloom material for Macoma. Feeding activities of the other species probably also resulted in increased dilution and burial of the fresh bloom material, contributing to the observed lower incorporation and much lower growth by Macoma in multispecies treatments. Interference competition among deposit-feeders has been found to reduce the access of competitors to freshly deposited organic matter (Nascimento et al. 2011). This mechanism may explain the low biomass increase in Macoma, resulting in the negative net effect on community biomass increase.

Previous studies have shown that the sub-surface-feeding amphipod Pontoporeia exhibits habitat separation by depth in the sediment and increased feeding on old organic matter when combined with other species, and in particular Monoporeia (Hill and Elmgren 1987; Byrén et al. 2006; Karlson et al. 2010). Such niche differentiation in organic matter utilization, i.e., that some species rely on bloom material while others feed primarily on aged organic matter (Byrén et al. 2006; Nascimento et al. 2008), increases resource utilization and thus promotes a positive biodiversity-ecosystem functioning relationship.

The invasive species Marenzelleria grew faster than all native species, both in treatments with bloom input and in the controls (Fig. 1). The latter indicates efficient utilization of old organic matter, a trait which has likely been important for the successful colonization and establishment of Marenzelleria populations in the Baltic Sea. This is further supported by the low $\delta^{13} \mathrm{C}$ initial values of this species (Table 1), indicating that sediment was an important part of its diet. Essink (1999) proposed that Marenzelleria spp. have been such successful invaders due to their filling an empty niche. Since Marenzelleria was not superior to the native species in incorporating bloom material, the partitioning model indicates low niche overlap and/or facilitative interactions between the invasive and the native species, rather than competition. Previous shortterm experimental studies have shown that Marenzelleria viridis may affect habitat selection by Monoporeia through inter-specific interference (Neideman et al. 2003) and competition for freshly deposited organic matter (Kotta and Ólafsson 2003). However, these two species only rarely cooccur in the Baltic Sea (Blank et al. 2008), and our results suggest that Marenzelleria arctia did not have such a negative effect on utilization of bloom material by the coexisting native species. Eriksson Wiklund et al. (2008) likewise found no evidence of negative interactions between Marenzelleria cf. arctia and Monoporeia in a short-term experiment.

However, once the spring bloom input to the sediment is exhausted, competition can be expected to intensify. The high conversion efficiency for old organic matter of Marenzelleria could translate directly into higher fitness and abundance and ultimately lead to competitive suppression of native species (Byers 2000). The Marenzelleria 
invasion has been considered responsible for the decline of Monoporeia in some parts of the Baltic Sea (Zettler et al. 2002). This seems unlikely in the study area, however, since the abundance of Monoporeia began decreasing in the late 1970s (Swedish National Marine Monitoring Program; Albertsson and Cederwall 2008), well before the introduction of Marenzelleria. Still, Marenzelleria abundances can reach densities of 30,000 ind $\mathrm{m}^{-2}$ (Zettler et al. 2002; personal observation) and might therefore hinder a potential recovery of the Monoporeia population. Marenzelleria is also more tolerant of poor oxygen conditions than, e.g., Monoporeia (Modig and Ólafsson 1998; Schiedek 1999) and has a long pelagic larvae phase (Bochert and Bick 1995). It could therefore potentially colonize sediments that would otherwise be devoid of fauna due to frequent hypoxic events, a widespread consequence of the ongoing eutrophication in the Baltic Sea.

Temporal differentiation in resource utilization among species (Bjelke et al. 2005) may contribute to maintaining high long-term productivity and allow for persistence of both native and the invasive species. Monoporeia is known to show rapid growth and increased fat content after the spring bloom of diatoms has settled to the bottom, both in the Baltic Sea (Elmgren 1978; Cederwall 1979; Hill et al. 1992) and in lakes (Johnson and Wiederholm 1992), while Pontoporeia, which feeds primarily on old organic matter (Byrén et al. 2006), displays a seasonally less variable growth (Cederwall 1979) and lipid content (Hill et al. 1992). The high incorporation of spring bloom material observed in Macoma could be related to the need to build up reproductive tissue at this time of the year, as it spawns after the bloom (Ankar 1980) whereas its lower incorporation of summer blooms of cyanobacteria, i.e., lower than both amphipods (Karlson et al. 2010), might be due to lower feeding activity during that time of the year. Lower incorporation of cyanobacteria than of diatoms might also be related to nutritional inadequacy (Nascimento et al. 2009) or toxin content of the cyanobacteria (Lehtonen et al. 2003). Considering also that both amphipods release their young after the spring bloom (Sundelin and Eriksson 1998), it seems likely that the native species are adapted to and dependent on the high quality input of organic matter of the spring bloom and that this bloom input might alleviate competition with Marenzelleria.

In conclusion, resource partitioning between Marenzelleria and the native species generally facilitated greater-than-expected incorporation of fresh bloom material, although interference competition (notably for $\mathrm{Ma}$ coma) dampened expected community biomass increase. Whether Marenzelleria is as efficient as the native species in further trophic transfer of incorporated sediment organic matter and bloom material, i.e., as fish food (Ehrenberg et al. 2005), remains to be studied. Release from predation is a well-known phenomenon contributing to invasion success (Keane and Crawley 2002) and could be important here, considering the deep burrowing behaviour of Marenzelleria spp. This study shows that, by making resource utilization more efficient, the addition of an invasive species to a species-poor community can enhance incorporation and burial of organic matter from settled phytoplankton blooms, two processes fundamental for marine productivity.

Acknowledgments This work was supported by grants from the Swedish Research Council and the Swedish Research Council Formas and Stockholm University's Research Programme on Baltic Ecosystem Adaptive Management to R.E. and from the Stockholm Centre for Marine Research to A.M.L.K. We thank the staff of the Askö Laboratory and O. Svensson for help during sampling and D. Jones, C. Bradshaw and three anonymous reviewers for constructive and helpful comments on the manuscript.

Open Access This article is distributed under the terms of the Creative Commons Attribution Noncommercial License which permits any noncommercial use, distribution, and reproduction in any medium, provided the original author(s) and source are credited.

\section{References}

Albertsson J, Cederwall H (2008) Känslig bottenfauna tappar mark, in Havet 2008 - om miljötillståndet i svenska havsområden (in Swedish). K. Viklund. Swedish Environmental Protection Agency, Stockholm, Sweden

Ankar S (1980) Growth and production of Macoma balthica (L.) in a northern Baltic soft bottom. Ophelia 1:31-48

Ankar S, Elmgren R (1976) The benthic macro- and meiofauna of the Askö-Landsort area, northern Baltic proper-a stratified random sampling survey. Askö laboratory, vol 11. University of Stockholm, Sweden

Bianchi TS, Johansson B, Elmgren R (2000) Breakdown of phytoplankton pigments in Baltic sediments: effects of anoxia and loss of deposit-feeding macrofauna. J Exp Mar Biol Ecol 251:161253

Bick A (2005) A new Spionidae (Polychaete) from North Carolina, and a redescription of Marenzelleria wireni Augener, 1913, from Spitsbergen, with a key for all species of Marenzelleria. Helgol Mar Res 59:265-272. doi:10.1007/s10152-005-0002-7

Bjelke U, Bohman IM, Herrmann J (2005) Temporal niches of shredders in lake littorals with possible implications on ecosystem functioning. Aquat Ecol 39:41-53

Blank M, Laine AO, Jürss K, Bastrop R (2008) Molecular species identification key based on PCR/RFLP for discrimination of three polychaete sibling species of the genus Marenzelleria, and their current distribution in the Baltic sea. Helgol Mar Res 62:129-141. doi:10.1007/s10152-007-0081-8

Bochert R, Bick A (1995) Reproduction and larval development of Marenzelleria viridis (Polychaeta: Spionidae). Mar Biol 123: 763-773

Bracken MES, Friberg SE, Gonzalez-Dorantes CA, Williams SL (2008) Functional consequences of realistic biodiversity changes in a marine ecosystem. Proc Natl Acad Sci USA 105:924-928. doi:10.1073/pnas.0806425105

Byers JE (2000) Competition between two estuarine snails: implications for invasions of exotic species. Ecology 81:1225-1239 
Byrén L, Ejdung G, Elmgren R (2006) The use of sedimentary organic matter by deposit-feeding amphipods, studied using three isotope tracers. Mar Ecol Prog Ser 313:135-143

Byrnes J, Stachowicz JJ (2009) Short and long-term consequences of increases in exotic species richness on water filtration by marine invertebrates. Ecol Lett 12:830-841. doi:10.1111/j.1461-0248. 2009.01339.x

Cardinale BJ, Srivastava DS, Duffy EJ, Wright JP, Downing AL, Sankaran M, Jouseau C (2006) Effects of biodiversity on the functioning of trophic groups and ecosystems. Nature 443:989-992. doi:10.1038/nature05202

Cederwall H (1979) Energy flow and fluctuations of deeper soft bottom communities in the Baltic sea. $\mathrm{PhD}$ dissertation, Askö Laboratory and Department of Zoology, Stockholm University, Sweden

Chapin FS III, Zavaleta ES, Eviner VT, Naylor RL, Vitousek PM, Reynolds HL, Hooper DU, Lavorel S, SalaI OE, Hobbie SE, Mack MC, Díaz S (2000) Consequences of changing biodiversity. Nature 405:234-242

Dauer DM, Maybury CA, Ewing RM (1981) Feeding behaviour and general ecology of several spionid polychaetes from the Chesapeake Bay. J Exp Mar Biol Ecol 54:21-38

Duffy JE (2009) Why biodiversity is important to the functioning of real-world ecosystems. Front Ecol Environ 7:437-444. doi: $10.1890 / 070195$

Duffy JE, Richardson JP, Canuel EA (2003) Grazer diversity effects on ecosystem functioning in seagrass beds. Ecol Lett 6:637-645

Ehrenberg SZ, Hansson S, Elmgren R (2005) Sublittoral abundance and food consumption of Baltic gobies. J Fish Biol 67:1083-1093

Elmgren R (1978) Structure and dynamics of Balthic benthos communities, with particular reference to the relationship between macro- and meiofauna. Kieler Meeresforsch Sonderh $4: 1-22$

Elmgren R, Hill C (1997) Ecosystem function at low biodiversitythe Baltic example. In: Ormond RFG, Gage JD, Angel MV (eds) Marine biodiversity, patterns and processes. Cambridge University Press, Cambridge, pp 319-336

Elmgren R, Ejdung G, Ankar S (2001) Intraspecific food competition in the deposit-feeding benthic amphipod Monoporeia affinis-a laboratory study. Mar Ecol Prog Ser 210:185-193

Elton C (1958) The ecology of invasions by animals and plants. Methuen, London

Eriksson Wiklund AK, Sundelin B, Rosa R (2008) Population decline of amphipod Monoporeia affinis in northern Europe: consequence of food shortage and competition? J Exp Mar Biol Ecol $367: 81-90$

Essink K (1999) Dispersal and development of Marenzelleria spp. (Polychaeta, Spionidae) populations in NW Europe and The Netherlands. Helgolander Meeresun 52:367-372

Fox JW (2005) Interpreting the 'selection effect' of biodiversity on ecosystem function. Ecol Lett 8:846-856

Gamfeldt L, Hillebrand H, Jonsson PR (2008) Multiple functions increase the importance of biodiversity for overall ecosystem functioning. Ecology 89:1223-1231

Graf G (1992) Benthic-pelagic coupling: a benthic view. Oceanogr Mar Biol Ann Rev 30:149-190

Guillard RRL (1975) Culture of phytoplankton for feeding marine invertebrates. In: Smith WL, Chanley MH (eds) Culture of marine invertebrate animals. Plenum, New York, pp 26-60

Heath RT, Fahnenstiel GL, Gardner WS, Cavaletto JF, Hwang SJ (1995) Ecosystem-level effects of zebra mussels (Dreissena polymorpha): an enclosure experiment in Saginaw Bay, Lake Huron. J Great Lakes Res 21:501-516

Hector A, Bazeley-White E, Loreau M, Otway S, Schmid B (2002) Overyielding in grassland communities: testing the sampling effect hypothesis with replicated biodiversity experiments. Ecol Lett 5:502-511

Hedman JE, Bradshaw C, Thorsson MH, Gilek M, Gunnarsson JS (2008) Fate of contaminants in Baltic sea sediments: role of bioturbation and settling organic matter. Mar Ecol Prog Ser 356:25-38. doi:10.3354/meps07218

Hietanen S, Laine AO, Lukkari K (2007) The complex effects of the invasive polychaetes Marenzelleria spp. on benthic nutrient dynamics. J Exp Mar Biol Ecol 352:89-102. doi:10.1016/j. jembe.2007.07.018

Hill C, Elmgren R (1987) Vertical distribution in the sediment in the co-occurring benthic amphipods Pontoporeia affinis and P. femorata. Oikos 49:221-229

Hill C, Quigley A, Cavaletto JF, Gordon W (1992) Seasonal changes in lipid content and composition in the benthic amphipods Monoporeia affinis and Pontoporeia femorata. Limnol Oceanogr 37:1280-1289

Höglander H, Larsson U, Hajdu S (2004) Vertical distribution and settling of spring phytoplankton in the offshore NW Baltic sea proper. Mar Ecol Prog Ser 283:15-27

Hooper DU, Chapin FS III, Ewel JJ, Hector A, Inchausti P, Lavorel S, Lawton JH, Lodge DM, Loreau M, Naeem S, Schmid B, Setälä H, Symstad AJ, Vandermeer J, Wardle DA (2005) Effects of biodiversity on ecosystem functioning: a consensus of current knowledge. Ecol Monogr 75:3-35

Johnson RK, Wiederholm T (1992) Pelagic-benthic coupling-the importance of diatom interannual variability for population oscillations of Monoporeia affinis. Limnol Oceanogr 37:15961607

Jonsson M, Malmqvist B (2000) Ecosystem process rate increases with animal species richness: evidence from leaf-eating, aquatic insects. Oikos 89:519-523

Karlson AML, Nascimento FJA, Näslund J, Elmgren R (2010) Higher diversity of deposit-feeding macrofauna enhances phytodetritus processing. Ecology 91:1414-1423

Keane RM, Crawley MJ (2002) Exotic plant invasions and the enemy-release hypothesis. Trends Ecol Evol 17:164-170

Kotta J, Ólafsson E (2003) Competition for food between the introduced polychaete Marenzelleria viridis (Verrill) and the native amphipod Monoporeia affinis Lindström in the Baltic sea. J Sea Res 50:27-35. doi:10.1016/S1385-1101(03)00041-8

Kristensen E (2000) Organic matter diagenesis at the oxic/anoxic interface in coastal marine sediments, with emphasis on the role of burrowing animals. Hydrobiology 426:1-24

Lehtonen KK, Kankaanpää H, Leiniö S, Sipiä VO, Pflugmacher S, Sandberg-Kilpi E (2003) Accumulation of nodularin-like compounds from the cyanobacterium Nodularia spumigena and changes in acetylcholinesterase activity in the clam Macoma balthica during short-term laboratory exposure. Aquat Toxicol 64:461-476. doi:10.1016/S0166-445X(03)00101-2

Leppäkoski E, Gollasch S, Gruszka P, Ojaveer H, Olenin S, Panov V (2002) The Baltic - a sea of invaders. Can J Fish Aquat Sci 59:1175-1188. doi:10.1139/F02-089

Lopez G, Elmgren R (1989) Feeding depths and organic absorption for the deposit feeding benthic amphipods Pontoporeia affinis and Pontoporeia femorata. Limnol Oceanogr 34:982-991

Loreau M, Hector A (2001) Separating selection and complementarity in biodiversity experiments. Nature 412:72-76 (erratum 413: 548)

Loreau M, Naeem S, Inchausti P, Bengtsson J, Grime JP, Hector A, Hooper DU, Huston MA, Raffaelli D, Schmid B, Tilman D, Wardle DA (2001) Biodiversity and ecosystem functioning: current knowledge and future challenges. Science 294:804-808

McKie BE, Woodward G, Hladyz S, Nistorescu M, Preda E, Popescu C, Giller PS, Malmqvist B (2008) Ecosystem functioning in stream assemblages from different regions: contrasting responses 
to variation in detritivore richness, evenness and density. J Anim Ecol 77:495-504. doi:10.1111/j.1365-2656.2008.01357.x

Modig H, Ólafsson E (1998) Responses of Baltic benthic invertebrates to hypoxic events. J Exp Mar Biol Ecol 229:133-148

Nascimento FJA, Karlson AML, Elmgren R (2008) Settling blooms of filamentous cyanobacteria as food for meiofauna assemblages. Limnol Oceanogr 53:2636-2643

Nascimento FJA, Karlson AML, Näslund J, Gorokhova E (2009) Settling cyanobacterial blooms do not improve growth conditions for soft bottom meiofauna. J Exp Mar Biol Ecol 368:138-146. doi:10.1016/j.jembe.2008.09.014

Nascimento FJA, Karlson AML, Näslund J, Elmgren R (2011) Diversity of larger consumers enhances interference competition effects on smaller competitors. Oecologia. doi:10.1007/s00442010-1865-0

Neideman R, Wenngren J, Ólafsson E (2003) Competition between the introduced polychaete Marenzelleria sp. and the native amphipod Monoporeia affinis in Baltic soft bottoms. Mar Ecol Prog Ser 264:49-55

Norling K, Rosenberg R, Hulth S, Grémare A, Bonsdorff E (2007) Importance of functional biodiversity and species specific traits of benthic fauna for ecosystem functions in marine sediment. Mar Ecol Prog Ser 332:11-23

Ólafsson E, Ullberg J, Arroyo NL (2005) The clam Macoma balthica prevents in situ growth of microalgal mats: implications for meiofaunal assemblages. Mar Ecol Prog Ser 298:179-188

Schiedek D (1999) Ecophysiological capability of Marenzelleria populations inhabiting North sea estuaries: an overview. Helgol Mar Res 52:373-382

Segerstråle S (1973) Results of bottom sampling in certain localities in the Tvärminne area (inner Baltic) with special reference to the so-called Macoma-Pontoporeia theory. Commentationes Biologicae Societas Scientiarum Fennicae 67:1-12

Shea K, Chesson P (2002) Community ecology theory as a framework for biological invasions. Trends Ecol Evol 17:170-176

Snelgrove P, Blackburn TH, Hutchings PA, Alongi DM, Grassle JF, Hummel H, King G, Koike I, Lambshead PJD, Ramsing NB, Solis-Weiss V (1997) The importance of marine sediment biodiversity in ecosystem processes. Ambio 26:578-583
Stachowicz JJ, Bruno JF, Duffy JE (2007) Understanding the effects of marine biodiversity on communities and ecosystems. Annu Rev Ecol Syst 38:739-766. doi:10.1146/annurev.ecolsys.38. 091206.095659

Sundelin B, Eriksson AK (1998) Malformations in embryos of the deposit-feeding amphipod Monoporeia affinis in the Baltic sea. Mar Ecol Prog Ser 171:165-180

Townsend CR (2003) Individual, population, community, and ecosystem consequences of a fish invader in New Zealand streams. Conserv Biol 17:38-47

van de Bund WJ, Ólafsson E, Modig H, Elmgren R (2001) Effects of the coexisting Baltic amphipods Monoporeia affinis and Pontoporeia femorata on the fate of a simulated spring diatom bloom. Mar Ecol Prog Ser 212:107-115

Vander Zanden MJ, Casselman JM, Rasmussen JB (1999) Stable isotope evidence for the food web consequences of species invasions in lakes. Nature 401:464-467

Viitasalo-Frösen S, Laine AO, Lehtiniemi M (2009) Habitat modification mediated by motile surface stirrers versus semi-motile burrowers: potential for a positive feedback mechanism in a eutrophied ecosystem. Mar Ecol Prog Ser 376:21-32. doi: 10.3354/meps07788

Vitousek P, D'antonio C, Loope L, Rejmanek M, Westbrooks R (1997) Introduced species: a significant component of humancaused global change. NZ J Ecol 21:1-16

Wilsey BJ, Teaschner TB, Daneshgar PP, Isbell FI, Polley HW (2009) Biodiversity maintenance mechanisms differ between native and novel exotic-dominated communities. Ecol Lett 12:432-442. doi:10.1111/j.1461-0248.2009.01298.x

Witte F, Goldschmidt T, Wannik J, Vanoijen M, Goudswaard K, Wittmass BN (1992) The destruction of an endemic species flock-quantitative data on the decline of the haplochromine cichlids of Lake Victoria. Environ Biol Fish 34:1-28

Zettler ML, Daunys D, Kotta J, Bick A (2002) History and success of an invasion into the Baltic sea: the polychaete Marenzelleria cf. viridis, development and strategies. In: Leppäkoski E, Gollasch S, Olenin S (eds) Invasive aquatic species of Europe: distribution, impacts and management. Kluwer, Dordrecht, pp 66-75 